\title{
PENJARINGAN CENDAWAN MIKORIZA ARBUSKULA INDIGENOUS DARI LAHAN PENANAMAN JAGUNG DAN KACANG KEDELAI PADA GAMBUT KALIMANTAN BARAT
}

\section{TRAPPING OF INDIGENOUS ARBUSCULAR MYCORIZA FUNGI FROMPHYSIC CORN AND NUTS AT PEATLAND WEST KALIMANTAN}

\author{
Nurmala Pangaribuan \\ Mahasiswa Pasca Sarjana Fakultas Pertanian Universitas Padjadjaran, Jl. Raya Jatinangor \\ Sumedang Km. 21 Sumedang
}

Korespondensi: nurmala6268@yahoo.com

Diterima 2 November 2014/ Disetujui 8 Desember 2014

\begin{abstract}
ABSTRAK
Ekosistem gambut memiliki jenis dan kepadatan CMA yang beragam. Tanaman yang dibudidayakan di lahan gambut memiliki sistem perakaran (rhizosfir) yang mengandung berbagai jenis mikroorganisme CMA, dan dalam jumlah besar. Untuk mengetahui jenis dan jumlahnya, perlu dilakukan studi potensi CMA indigenous pada ekosistem gambut. Penelitian ini bertujuan untuk dapat memberikan informasi yang tepat tentang potensi sumberdaya cendawan mikoriza arbuskular dari lokasi penanaman jagung dan kacang-kacangan pada lahan gambut desa Sidomulyo Rasau Jaya, kabupaten Kubu Raya dan dari Jawai di Kabupaten Sambas, Propinsi Kalimantan Barat. Kegiatan penelitian ini diawali dengan pengambilan sampel tanah dari Rasau dan Jawai, yang kemudian diamati dengan mikroskop. Selanjutnya dilakukan (1) trapping spora mengunakan tanaman Jagung (Zea mays L.), (2) identifikasi jenis spora, identifikasi CMA menggunakan Manual for The Identification of Mychorhiza Fungi, (3) penghitungan jumlah spora dengan menggunakan Metode Saring Basah Pacioni dan teknik sentrifugasi dari Brunndret. Hasil percobaan menghasilkan jumlah spora Glomus sp. asal Rasau 227 spora per $50 \mathrm{~g}$ tanah, dan gambut asal Jawai 181,9 spora per $50 \mathrm{~g}$ tanah gambut Rasau dan Sambas dominan mengandung Glomus sp.
\end{abstract}

Kata kunci : Gambut, Glomus sp., Indigenous, Kalimantan Barat, Trapping

\begin{abstract}
Peats ecosystem has different species and densities of Arbuscular Mycoriza Fungi (AMF). Plant Rhizosphere at peatland has various kinds of microorganisms, including AMF. For further use, study the potency of indigenous AMF is necessary. This research was conducted to study on the potency of indigenous AMF, from the where physic corn and nuts, grow on peatland of Rasau dan Jawai, Pontianak West Kalimantan. Soils samples were collected and then observed under microscope. The steps to study the potency of AMF were (1) spora trapping, (2) identifying the types of spore, and (3) counting of spora with Seive and Wet Techniques by Pacioni and Brunndret. The result showed that the number of spores AMF of Glomus sp from cultivated Rasau was 227 spores $50 \mathrm{~g}^{-1}$ soil and from of Jawai was 181,9 spores $50 \mathrm{~g}^{-1}$ soil
\end{abstract}


Indigenous AMF from the soil where physic corn and nut grown at Rasau and Jawai were dominated by Glomus sp.

Key words: Glomus sp., Indigenous, Peats, West Kalimantan

\section{PENDAHULUAN}

Mikoriza adalah asosiasi antara akar tumbuhan dan jamur yang hidup dalam tanah (Brundrett et al., 1996). Mikoriza berperan dalam peningkatan penyerapan unsur-unsur hara tanah yang dibutuhkan oleh tanaman seperti $\mathrm{P}, \mathrm{N}, \mathrm{K}, \mathrm{Zn}, \mathrm{Mg}, \mathrm{Cu}$, dan Ca. Salah satu alternatif untuk mengatasi kekurangan unsur hara terutama menmfasilitasi ketersediaan fosfat dalam tanah adalah dengan penggunaan mikoriza. Pemanfaatan Mikoriza merupakan masukan teknologi mikrobia yang mungkin dapat dikembangkan untuk mengatasi masalah pada tanah yang sub optimal.

Gambut termasuk tanah yang sub optimal, yang pada kondisi alami tanaman pertanian umumnya sulit tumbuh. Sebagai media tanam gambut memiliki faktor penghambat dalam kesuburan kimia, yang disebabkan $\mathrm{pH}$ rendah, kejenuhan basa rendah, KTK tinggi, drainase yang buruk, rasio $\mathrm{C} / \mathrm{N}$ tinggi, sehingga ketersediaan hara makro dan mikro bagi tanaman rendah (Rachim, 1995).

Sebaran mikoriza dipengaruhi oleh banyak faktor antara lain jenis dan struktur tanah, unsur hara $\mathrm{P}$ dan $\mathrm{N}$ dalam tanah, air, $\mathrm{pH}$, dan suhu tanah (Widiastutik dan Karmadibrata, 1998). Hasil penelitian (Kartika, 2000), pada tanah gambut bekas hutan, jenis CMA yang mendominasi di rhizosfer kelapa sawit adalah Glomus, $s p$. Di desa Torjun Madura, isolasi dari 500 gram contoh tanah asal rizosfer tanaman jagung (Zea mays L.) ditemukan kelimpahan spora jenis Glomus sp. sebanyak 482, Acaulospora sp. sebanyak 95 dan jenis Gigaspora sp. sebanyak 281 (Puspitasari et al., 2012). Lingkungan dan faktor biotik diketahui memiliki pengaruh terhadap pembentukan mikoriza dan derajat infeksi dari sel korteks inang. Interaksi antar faktor-faktor biotik memiliki efek yang signifikan dalam merespon pertumbuhan tanaman yang diinokulasi.. Keanekaragaman dan penyebaran mikoriza sangat bervariasi, hal ini dapat disebabkan oleh kondisi lingkungan yang bervariasi juga. Semua mikoriza tidak mempunyai sifat morfologi dan fisiologi yang sama, oleh karena itu sangat penting untuk mengetahui identitasnya. Dengan alasan tersebut penelitian ini mengisolasi mikoriza dari dua lokasi gambut di Kalimantan Barat. Sebelum melakukan isolasi Vesicular Arbuscular Mycorrhiza (VAM) Indigenous, dilakukan traping dengan menggunakan tanaman jagung. Untuk mengetahui jenis mikoriza pada rhizosfer tanaman jagung, dilakukan identifikasi untuk mengetahui jumlah dan jenisnya.

Mikoriza sebagai mikroorganisme berperan dalam susunan tanah dengan mempengaruhi kondisi fisik dan kimia tanah. Mikoriza menggantungkan kebutuhan akan energi dan karbon pada bahan organik. Tanpa aktivitas mikroorganisme dekomposisi, pelapukan bahan organik dan pendauran unsur hara tidak akan terjadi. Pada kondisi masam gambut beberapa populasi mikroorganisme dapat hidup. Hal ini berhubungan positif dengan kadar air, $\mathrm{pH}$, 
C-organik, dan $\mathrm{N}$ total tanah gambut. Hal ini menjelaskan bahwa ada mikroorganisme mampu hidup pada tanah gambut dengan bahan organik tinggi, dengan cara mendekomposisi bahan organik. Populasinya sangat tergantung pada keberadaan bahan organik (Maftu'ah, 2002). Sebagian dari mikrooorganisme ini juga berperan besar dalam pelepasan $\mathrm{N}$ dari bahan organik dengan rasio $\mathrm{C} / \mathrm{N}$ tinggi (bahan organik kualitas rendah).

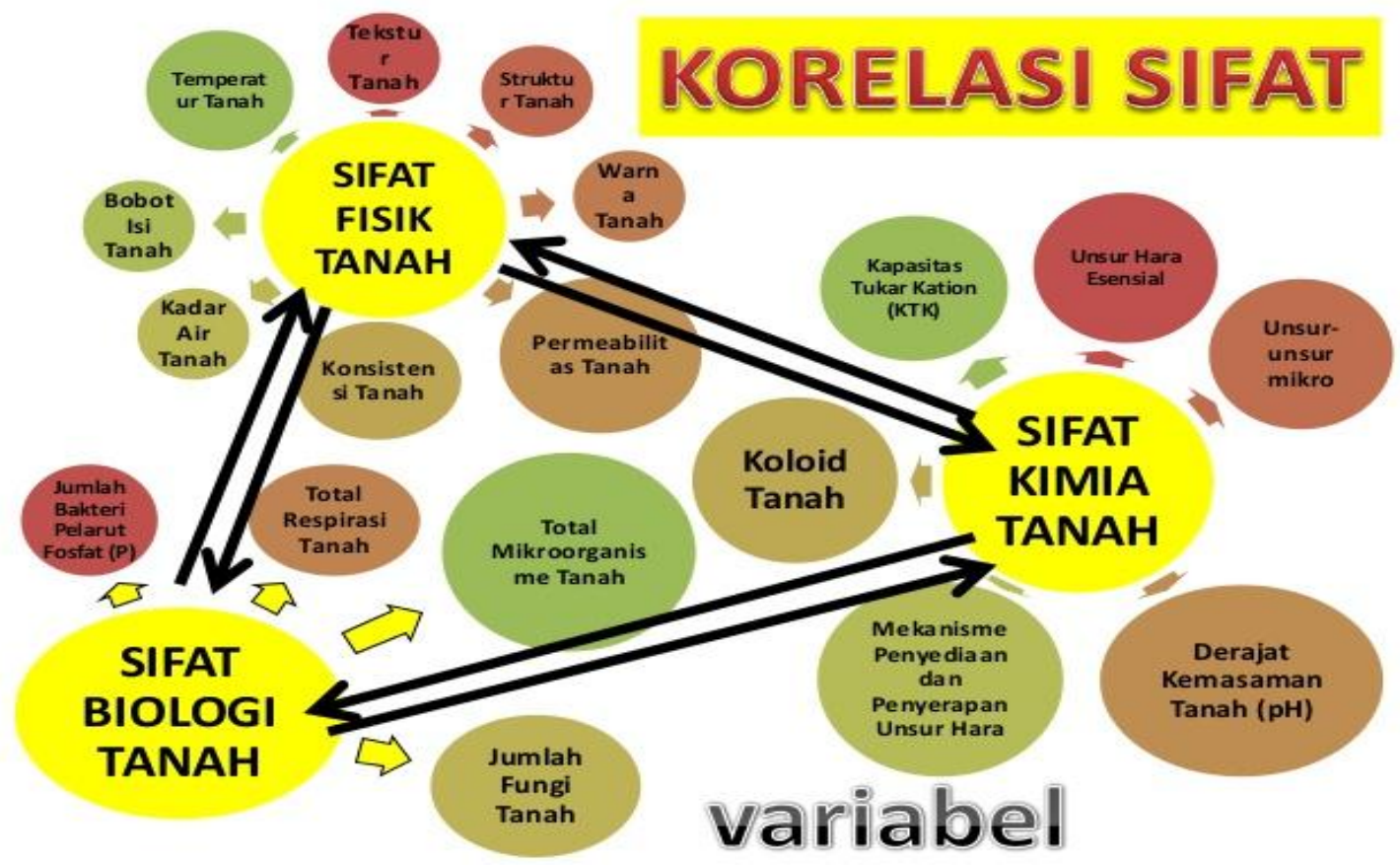

Gambar 1. Korelasi antar sifat fisik, kimia dan biologi tanah

\section{BAHAN DAN METODE}

Penelitian diawali dengan percobaan trapping pada bulan September 2013 di kebun percobaan Fakultas Pertanian, pelaksanaan isolasi Glomus sp. dilakukan di Laboratorium Hama dan Penyakit dan Laboratorium Kesuburan Tanah Fakultas Pertanian Universitas Tanjung Pura Pontianak.

\section{Pengambilan contoh tanah}

Pengambilan contoh tanah dilakukan di desa Sidomulyo Rasau dan desa Sarang Burung Nilam Jawai. Pengambilan contoh tanah dilakukan di Propinsi Kalimantan Barat, yaitu dari ekosistem kebun jagung, kacang kacangan. Contoh tanah diambil dari zona perakaran (rizosfir) jagung dengan kedalaman 0-20 cm, kemudian dimasukkan ke dalam kantong plastik dan diberi label dari masing masing lokasi asal tanah. Contoh tanah merupakan komposit dari 20 titik pengambilan contoh, dimana masing-masing titik banyaknya $250 \mathrm{~g}$.

2. Analisa sifat fisik dan kimia tanah Analisa sifat fisik dan kimia tanah dilakukan di Laboratorium Kesuburan Tanah Fakultas Pertanian UNTAN Pontianak. Analisis sifat fisik dan kimia yang dilakukan adalah tekstur tanah, $\mathrm{pH}, \mathrm{N}$, $\mathrm{P}$, dan K. Analisis kandungan sifat fisik dan kimia tanah bertujuan untuk mengetahui keberadaan CAM. Keadaan tanah sangat mempengruhi populasi, kolonisasi dan jenis mikoriza. 
3. Trapping Glomus sp. dengan tanaman jagung

Trapping dilakuakan pada bulan September 2013 di kebun percobaan Fakultas Pertanian, Universitas Tanjung Pura Pontianak. Pengambilan contoh tanah dilakukan di desa Sidomulyo Rasau dan desa Sarang Burung Nilam Sambas. Trapping mikoriza menggunakan tanaman jagung varitas lokal. Percobaan menggunakan Rancangan Acak Lengkap, contoh tanah gambut sebagai sumber media (carrier) dari dua lokasi contoh tanah diambil secara komposit dari 20 titik, pada kedalaman $0-20 \mathrm{~cm}$ dari permukaan tanah karena spora mikoriza banyak ditemukan pada bagian top soil. Setiap lokasi terdiri dari 10 polibag (sebagai ulangan). Isolat asal Rasau (IR) dan Isolat asal Jawai (IS) 10 ulangan, sehingga total satuan percobaan adalah 20. Teknik trapping yang digunakan mengikuti metode Brundrett et al. (1994) dengan menggunakan polibag kecil ukuran tiga kilogram. Media tanam yang digunakan berupa campuran contoh tanah. Polibag diisi contoh tanah masing-masing dua kilogram. Setiap polibag ditanami dua benih jagung. Benih jagung yang akan digunakan sebagai tanaman inang terlebih dahulu direndam dengan klorox $5 \%$ selama 5-10 menit sebagai upaya sterilisasi permukaan benih, kemudian dicuci sampai bersih dengan air mengalir. Selanjutnya benih dikecambahkan. Setelah berkecambah dipindahkan ke polibag. Penyiraman bersamaan dengan pemberian hara Hyponex 25-5-20, dosis pemberian $0,5 \mathrm{~g} \mathrm{~L}^{-1}$ air, diberikan dua kali seminggu sampai vase akhir vegetatif (Faiqoh, 1999). Setelah 35 HST tanaman dipanen, tanah dan tanaman dipisah. Kemudian dari sepuluh polibag masing-masing diambil 250 gram, dibawa ke laboratorium untuk dilakukan proses penyaringan. Selain identifikasi mikoriza dilakukan juga analisis tanah, kondisi dan sifat tanah sangat mempengaruhi populasi, kolonisasi, dan jenis mikoriza.

Tabel 1. Sifat Tanah Gambut Rasau dan Sambas

\begin{tabular}{lrr}
\hline \multicolumn{1}{c}{ Sifat Tanah } & Rasau & Sambas \\
\hline $\mathrm{pH}$ & 4,01 & 5,10 \\
$\mathrm{C}$ & 51,33 & 12,00 \\
$\mathrm{~N}(\%)$ & 1,53 & 0,74 \\
$\mathrm{P}_{2} \mathrm{O}_{5}(\mathrm{P}-\mathrm{Bray} \mathrm{I}) \mathrm{ppm}$ & 123,31 & 39,92 \\
$\mathrm{KTK}$ & 100,61 & 23,52 \\
$\mathrm{~KB}(\%)$ & 4,26 & 11,86 \\
$\mathrm{~K}\left(\mathrm{cmol}(+) \mathrm{kg}^{-1}\right)$ & 0,77 & 0,50 \\
$\mathrm{Na}\left(\mathrm{cmol}(+) \mathrm{kg}^{-1}\right)$ & 1,17 & 0,76 \\
$\mathrm{Ca}\left(\mathrm{cmol}(+) \mathrm{kg}^{-1}\right)$ & 1,81 & 1,18 \\
$\mathrm{Mg}\left(\mathrm{cmol}(+) \mathrm{kg}^{-1}\right)$ & 0,54 & 0,35 \\
\hline
\end{tabular}

4. Pengambilan propagul dari
penanaman jagung
Isolasi Glomus sp. dilakukan di laboratorium Hama dan Penyakit Tanaman Fakultas Pertanian UNTAN. Bahan utama yang digunakan adalah propagul dari daerah penanaman jagung. Propagul yang diambil berupa tanah sampel dan akar tanaman yang mengandung mikoriza, yang diambil dari daerah perakaran tanaman jagung. Bahan lain yang digunakan adalah bahan kimia untuk mengekstraksi spora mikoriza dari tanah, untuk mencuci atau membersihkan akar, dan untuk 
mengindentifikasi spora CMA, dan bahan yang digunakan sebagai media tumbuh tanaman inang serta benih tanaman jagung Alat-alat yang digunakan antara lain botol vial, pinset, saringan kasa, oven, mikroskop.

Pengamatan spora awal dilakukan di bawah mikroskop. Ekstraksi CMA dilakukan untuk memisahkan spora dari contoh tanah sehingga dapat diamati keberadaan spora. Teknik yang digunakan adalah teknik tuang-saring dari Pacioni (1992) dan dilanjutkan dengan teknik sentrifugasi dari Brundrett et al. (1996). Prosedur untuk teknik tuang-saring ini menggunakan contoh tanah sebanyak 50 gram ditambah dengan 200-300 ml air, lalu diaduk sampai butiran-butiran tanah hancur, kemudian didiamkan selama \pm 2-5 menit. Prosedur kerja teknik penyaringan basah adalah mencampurkan tanah sampel sebanyak $200 \mathrm{~g}$ dengan 1000-1200 ml air dan diaduk merata. Selanjutnya disaring dalam satu set saringan bertingkat dengan ukuran 550 $\mu \mathrm{m}, 250 \mu \mathrm{m}$, dan $125 \mu \mathrm{m}$ secara berurutan dari atas ke bawah (Metode Penyaringan Basah). Dari saringan bagian atas disemprot dengan air kran untuk memudahkan bahan saringan lolos. Kemudian saringan paling atas dilepas dan saringan kedua kembali disemprot dengan air kran. Tanah yang tersisa pada saringan $250 \mu \mathrm{m}, 125 \mu \mathrm{m}$ dipindahkan ke dalam tabung sentrifuse. Kemudian ditambahkan aquades sebanyak $25 \mathrm{ml}$ dan disentrifuse dengan kecepatan 2000 RPM selama 5 menit. Hasil sentifuse dibuang supernatannya kemudian ditambahkan glukosa $60 \%$. Tabung sentifuse ditutup rapat dan disentrifugasi kembali dengan kecepatan 2000 RPM selama 1 menit. Selanjutnya larutan supernatan tersebut dihisap dengan pipet hisap dan dituangkan ke dalam saringan $45 \mu \mathrm{m}$, dicuci dengan air mengalir (air kran) untuk menghilangkan glukosa. Endapan yang tersisa dalam saringan di atas dituangkan ke dalam cawan petri plastik dan kemudian diamati di bawah stereoskop untuk identifikasi dan jumlah spora.

\section{Identifikasi spora}

Spora yang tersaring diidentifikasi dengan menggunakan mikroskop, dan pinset spora. Spora hasil identifikasi dikumpulkan berdasarkan karakter morfologi spora meliputi bentuk spora, ukuran spora, warna spora, susunan spora, spora dengan susunan tunggal atau mengumpul menjadi satu yang disebut sporokap; bentuk hifa, silindris, kerucut, bergelombang dan bercabang banyak; ukuran spora, bentuk spora berbentuk bulat globe, sub globose, oval dan oblong. Identifikasi dilakukan berdasarkan respon spora terhadap PVLG dan pewarna Melzer's serta karakter morfologi. Spora hasil isolasi diamati di bawah mikroskop.

Tahapan identifikasi CMA berdasarkan karakteristik morfologi spora meliputi:

a. Susunan spora: susunan tunggal atau mengumpul menjadi satu yang disebut sporokap.

b. Bentuk hifa: silindris, kerucut, bergelombang dan bercabang banyak.

c. Ukuran spora: ukuran terkecil dari 10$50 \mu \mathrm{m}$ sampai 200-300 $\mu \mathrm{m}$.

d. Warna spora: menggunakan standar colour chart. berkisar hialin kuning, kuning kehijauan, coklat, coklat kemerahan sampai coklat hitam

e. Bentuk spora : secara umum bentuk spora adalah bulat globe, sub globose, oval dan

Tahapan identifikasi dilakukan dengan menggunakan Manual for The Identification of Mychorhiza Fungi (Brundrett et al., 1996). 
6. Penghitungan jumlah spora

Setelah di identifikasi spora yang diperoleh dari ekstraksi dihitung jumlahnya, diletakkan dalam larutan Melzer's dan PVLG pada satu kaca preparat. Selanjutnya spora-spora tersebut dipecahkan secara hati-hati dengan cara menekan kaca penutup preparat menggunakan ujung pinset spora. Variabel yang diamati meliputi (peubah), jumlah spora per $50 \mathrm{~g}$ media tanam serta tipe spora, dengan menggunakan mikroskop binual.

\section{HASIL DAN PEMBAHASAN}

Hasil identifikasi menunjukkan pada kedua lokasi ditemukan Glomus sp. Ukuran spora Glomus berkisar 20-200 $\mu \mathrm{m}$; susunannya mengumpul berupa sporokarp, warna spora kuning sampai cokelat kemerahan. Spora Glomus yang ditemukan rata-rata memiliki bentuk bulat sampai bulat lonjong, memiliki dinding spora mulai dari kuning bening sampai coklat kemerahan, permukaan dinding spora relatif halus, dan memiliki dinding spora yang tipis. Spora yang ditemukan ada yang melekat dengan hifa dan ada pula yang tidak. Hifa pada spora yang ditemukan langsung menyatu dengan dinding spora dengan warna yang hampir sama dengan dinding spora.

Pada kedua lokasi dominan ditemukan CMA jenis Glomus sp. Hal ini sesuai dengan temuan (Sasli, 2012), bahwa Glomus mempunyai tingkat adaptasi yang cukup tinggi terhadap lingkungan tanah yang masam. Perkembangan spora Glomus adalah dari ujung hifa. Ujung hifa akan membesar sampai mencapai ukuran maksimal dan terbentuk spora. Karena sporanya berasal dari perkembangan hifa maka disebut chlamydospora. Hifa bercabang-cabang dan tiap cabang terbentuk chlamydiospora dan membentuk sporokarp. Karakteristik khasnya pada Glomus terlihat jelas sisa dinding hifa pada permukaan spora.

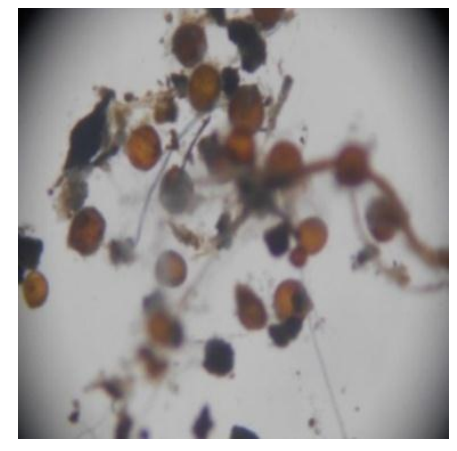

(a)

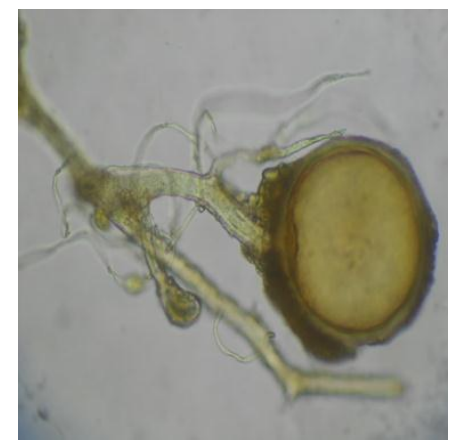

(b)

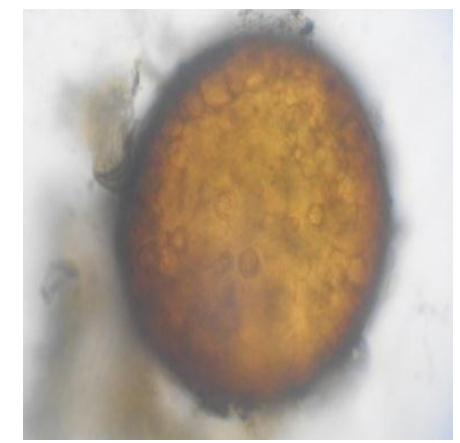

(c)

Gambar 2. (a) Kumpulan Glomus sp. indigenus (b) hifa, spora Glomus sp. (c) spora bentuk normal

Hasil penghitungan di bawah mikroskop menunjukkan bahwa jumlah spora asal Rasau Jaya lebih tinggi dibandingkan jumlah spora asal Jawai (Tabel 2). Jumlah spora asal contoh tanah Rasau adalah 227 dan jumlah spora dari Jawai adalah 182.
Hal ini diperkuat oleh temuan (Sasli et al., 2012), bahwa CMA Glomus sp mempunyai tingkat adaptasi yang cukup tinggi terhadap lingkungan tanah yang masam. Hasil ini juga diperkuat oleh hasil analisa tanah kedua lokasi, yang menunjukkan bahwa kadar bahan organik 
contoh tanah asal Rasau lebih tinggi yaitu $51,33 \%$ dengan $\mathrm{pH} 4,0$, dan contoh tanah asal Jawai $12,00 \%$ dengan $\mathrm{pH} \quad 5,10$. Tanaman jagung efektif untuk menjaring Glomus sp. pada gambut. Hasil isolasi Glomus sp. pada gambut lebih tinggi dibanding pada tanah mineral (Puspita, 2012).

Jumlah spora dari isolasi Glomus sp. dari gambut Rasau dan Jawai dapat menjawab kekhawatiran penelitian Simanungkalit (2003) dan Twin (2003), tentang pengadaan, memproduksi inokulan mikorhiza dalam skala besar masih sulit. Gambut dapat digunakan sebagai sumber inokulan alami dalam jumlah besar. Kepadatan spora juga mempunyai perbedaan pada setiap asal tanah yang berbeda penggunaannya. Awalnya contoh tanah asal Rasau merupakan kebun Jagung, dan gambut Jawai merupakan kebun kacang-kacangan dan sayuran yang intensif diusahakan.

Tabel 2. Jumlah spora Glomus sp. pada gambut Rasau dan Jawai

\begin{tabular}{|c|c|c|c|c|c|c|c|c|c|c|c|c|}
\hline \multirow{3}{*}{ Lokasi } & \multicolumn{10}{|c|}{ JUMLAH SPORA } & \multirow{3}{*}{ Jumlah } & \multirow{3}{*}{ Rataan } \\
\hline & \multicolumn{10}{|c|}{ ULANGAN } & & \\
\hline & 1 & II & III & IV & $\mathrm{V}$ & $\mathrm{VI}$ & VII & VIII & IX & $x$ & & \\
\hline Rasau (IR) & 260 & 210 & 235 & 270 & 220 & 211 & 200 & 220 & 223 & 218 & 2267 & 226,7 \\
\hline Jawai (IJ) & 178 & 220 & 127 & 168 & 200 & 181 & 179 & 199 & 169 & 198 & 1819 & 181,9 \\
\hline
\end{tabular}

Sebelum dilakukan trapping, kepadatan spora alami pada kedua asal tanah hanya ditemukan $18-30$ spora dalam setiap 50 gram contoh tanah. Hasil ini lebih rendah dibandingkan hasil penelitian Widiastuti (2004) yang mendapatkan 3-103 spora dalam setiap 100 gram tanah pada daerah perakaran kelapa sawit. Rendahnya kepadatan spora alami pada rizosfer pertanaman jagung (Rasau) dan kacangkacangan (Jawai), diduga pada saat mengambil contoh tanah, CMA belum bersporulasi, jadi pada contoh tanah tersebut lebih banyak mengandung bagian lain seperti hifa eksternal. Pengamatan didukung oleh terjadinya peningkatan kepadatan spora ketika dilakukan trapping dengan menggunakan tanaman inang jagung (Zea mays L.). Kepadatan spora ekosistem dari kedua lokasi contoh tanah meningkat. Rataan spora asal Rasau menjadi 226,7 dan Jawai 181,9 spora dalam 50 gram contoh tanah. Penemuan ini juga diperkuat oleh hasil penelitian Kartika (2006) bahwa sporalisasi dipengaruhi oleh musim pada waktu pengambilan sampel tanah. Jumlah propagul di setiap rizosfer dari asal tanah yang berbeda menghasilkan jumlah propagul berbeda. Perbedaan jumlah spora Glomus sp. juga dapat disebabkan oleh keragaman tanaman dan kondisi lingkungan asal contoh tanah. Menurut Basrudin (2005), kolonisasi dan pembentukan spora CMA dipengaruhi oleh masing-masing eksudat akar tanaman inang.

Faktor lain yang juga mempengaruhi pembentukan spora adalah pertumbuhan tanaman inang. Pertumbuhan tanaman jagung asal propagul Rasau (IR), lebih baik dibandingkan dengan tanaman jagung yang tumbuh dari propagul asal Jawai. Rata-rata tinggi tanaman dan panjang akar masing-masing Rasau (IR) 26,4 cm, dan $35,36 \mathrm{~cm}$, sementara Jawai (IJ) tinggi ratarata 19,6 cm, dan panjang akar $27,65 \mathrm{~cm}$. Data disajikan pada Tabel 3. 
Tabel 3. Hasil Pengamatan Tinggi Tanaman Panjang Akar pada Percobaan Trapping Glomus

\begin{tabular}{ccc}
\hline Perlakuan & $\begin{array}{c}\text { Tinggi } \\
\text { Tanaman }\end{array}$ & $\begin{array}{c}\text { Panjang } \\
\text { Akar }\end{array}$ \\
\hline \multirow{3}{*}{ IJ (Jawai) } & 21 & 30 \\
& 20 & 31 \\
& 21 & 30,5 \\
& 18 & 27 \\
& 20 & 28 \\
& 18 & 29 \\
& 18 & 32 \\
& 22 & 30 \\
& 19 & 31 \\
\hline RATAAN & 19 & 28 \\
\hline IR (Rasau) & $\mathbf{1 9 , 6}$ & $\mathbf{2 7 , 6 5}$ \\
& 26 & 37,0 \\
& 26,8 & 35,2 \\
& 25 & 35,0 \\
& 26 & 34,8 \\
& 25 & 37,3 \\
& 27 & 32,9 \\
& 24 & 36,8 \\
& 26,7 & 34,9 \\
& 29 & 34,6 \\
\hline RATAAN & 28,5 & 35,1 \\
\hline
\end{tabular}

Pertumbuhan tanaman yang normal, jagur, akan menghasilkan fotosintat lebih banyak, sehingga memiliki karbon yang dapat digunakan oleh mikoriza, karena mikoriza membutuhkan karbon untuk hidupnya. Pada keadaan dimana pertumbuhannya tanaman yang baik memungkinkan untuk bersimbiosis dengan mikoriza secara optimal. Perbedaan asal propagul dan jumlah kepadatan spora kemungkinan dapat juga disebabkan oleh adanya perbedaan lingkungan antara Rasau yang masuk dalam wilayah kabupaten Sungai Raya, dan Jawai di Kabupaten Sambas. Diduga kedua contoh tanah tersebut mempunyai perbedaan hara tanaman dan cara pengelolaan tanah. Propagul tanah asal Rasau menghasilkan jumlah spora lebih banyak dibanding propagul asal Jawai. Hasil analisis tanah awal Rasau dan Tanah asal Sambas juga mendukung hal tersebut (Tabel 1). Ketersediaan hara yang rendah akan mengoptimalkan kerja mikoriza dengan memperluas daerah penyerapan sekaligus juga dapat menembus daerah penipisan nutrient (zone of nutrient depletion).

Populasi spora CMA, seperti Glomus sp. yang tinggi juga diduga disebabkan kondisi lingkungan yang lebih sesuai, optimal, dan kompatibel dalam mendukung pertumbuhan dan perkembangan spora. Ditunjang lagi oleh kemungkinan tidak adanya jamur antagonis yang menghambat sporulasi CMA. Faktor lainnya, perbedaan lingkungan asal tanah, hara, ketinggian tempat, curah hujan, cahaya pada kedua contoh tanah memungkinkan adanya perbedaan kepadatan spora.

Tabel 4. Data Komponen Iklim per Bulan

\begin{tabular}{clcc}
\hline No. & \multicolumn{1}{c}{ Komponen Iklim } & Rasau & Jawai \\
\hline 1. & Rata-rata Curah hujan $(\mathrm{mm})$ & $100-425,4$ & $187-348$ \\
2. & Temperatur rata-rata $\left({ }^{\circ} \mathrm{C}\right)$ & $26,2-27,70$ & $22,9-31,05$ \\
3. & Jumlah hari hujan (hari) & 16,60 & 11,00 \\
4. & Kelembaban udara Relatif (\%) & 83,00 & 81,90 \\
5. & Tekanan udara (Hm Bar) & $1,001-1,10$ & $1,001-1,01$ \\
6. & Kecepatan angin $\left(\mathrm{km} \mathrm{hari}^{-1}\right)$ & $145-177$ & $153-173$ \\
7. & Elipasi sinar matahari (\%) & 58,30 & 50,73 \\
8. & Penguapan harian (Hm) & $4,1-6,0$ & $4,2-5,9$ \\
9. & Evapotranspirasi bulanan $(\mathrm{mm})$ & $134,7-181,7$ & $134,7-171,4$ \\
\hline
\end{tabular}

Sumber: BMKG Supadio, Pontianak 20 Juni 2014. 
Jawai dan Rasau termasuk daerah beriklim tropis. Jawai masuk wilayah Kabupaten Sambas, dengan curah hujan tertinggi pada bulan September sampai dengan Januari, dan terendah pada bulan Juni sampai dengan bulan Agustus. Suhu udara terendah $21,2^{\circ} \mathrm{C}$ pada bulan Agustus dan tertinggi $33^{\circ} \mathrm{C}$ pada bulan Juli. Sementara Rasau Jaya masuk wilayah Kabupaten Kubu Raya. Iklim di Kubu Raya termasuk type Iklim A (Schmit \& Ferguson) yaitu iklim sangat basah dengan curah hujan bulanan diatas $100 \mathrm{~mm}$ dengan total curah hujan tahunan rata-rata berkisar $3000 \mathrm{~mm}$ rata-rata bulan basah mencapai tujuh bulan pertahun, yaitu Agustus, September, sampai Februari. Curah hujan terendah pada bulan Juli rata-rata 144,2 $\mathrm{mm}$ dan tertinggi pada bulan Oktober mencapai 533,5 mm. Kabupaten Kubu Raya secara umum merupakan dataran rendah yang relatif datar. Dengan suhu udara yang tinggi, panas, ditambah lagi oleh karena dekat dengan garis khatulistiwa. Suhu ratarata maksimum $33,40^{\circ} \mathrm{C}$ terjadi pada bulan Mei, dan suhu minimum rata-rata $22,50^{\circ} \mathrm{C}$ terjadi pada bulan Agustus.

Menurut Rainiyati (2007), terdapat kecenderungan peningkatan jumlah spora dengan berkurangnya jumlah curah hujan, fluktuasi kelembapan tanah juga dapat mempengaruhi pembentukan spora atau sporulasi. Lebih jauh Johansson (2003), kekeringan tidak menghambat pertumbuhan mikoriza namun meningkatkan perkembangan akar lateral dan setelah pembasahan kembali laju pemanjangan akar dan jumlah mikoriza meningkat dengan cepat. Struktur jamur (terutama arbuscules bercabang) meningkatkan luas permukaan, jangkauan atau jelajah akar sehingga memungkinkan pengoptimalan kegiatan pertukaran metabolik antara tanaman dan jamur walau kondisi kurang baik. Pernyataan ini juga berkaitan dengan laporan Yusnaini et al. (1999), bahwa penggunaan CAM ini dapat meningkatkan produksi jagung walau mengalami kekeringan sesaat pada fase vegetatif dan generatif. Lebih jauh Setiadi (2003), melaporkan bahwa mikoriza berperan dalam meningkatkan toleransi tanaman terhadap kondisi lahan kritis, kekeringan dan terdapatnya logam-logam berat. Kolonisasi akar tanaman dengan CMA dapat mempengaruhi komunitas yang berasosiasi dengan akar langsung dan tidak langsung. Interaksi langsung termasuk penyediaan senyawa karbon yang kaya energi, perubahan $\mathrm{pH}$ mycorrhizosphere, kompetisi nutrisi, dan eksudasi jamur dari penghambatan atau stimulasi senyawa. Interaksi langsung juga juga dapat terjadi dalam bentuk efek mikoriza pada pertumbuhan tanaman inang, hasil eksudasi akar dan perbaikan struktur tanah (Johansson, 2004).

\section{SIMPULAN}

Spora Glomus sp. berhasil diisolasi dan diidentifikasi dari rhizosfer jagung (Zea mays L.) dari gambut asal Rasau dan Jawai. Percobaan menunjukkan bahwa Glomus sp. dominan dijumpai pada kedua lokasi contoh tanah. Bentuk spora umumnya berbentuk bulat globe, dengan warna kuning sampai coklat kemerahan. Tanaman jagung hibrida, dapat digunakan untuk menjaring Glomus sp. pada gambut. Ditinjau dari jenis isolat CMA, Glomus sp. dominan di jumpai di gambut. Kelimpahan spora CAM di Rasau ditemukan jumlah spora jenis Glomus sp. sebanyak 226,7 dan di Jawai 181,9. Penemuan ini menjadi 
harapan baru untuk memanfaatkan gambut sebagai upaya memenuhi kebutuhan pupuk hayati dalam jumlah besar dan murah. Perlu dilakukan pengkajian lebih lanjut untuk lebih mengetahui tentang kemampuan CMA sebagai bahan baku pupuk hayati (puhay) yang menunjang perkembangan pertanian di Kalimantan Barat. Kajian lanjut juga diharapkan memberi masukan, dalam upaya pengurangan pemakaian pupuk anorganik dan atau mensubstitusi kebutuhan hara dengan pupuk hayati. Ditambah lagi dengan peran mikoriza dalam meningkatkan toleransi tanaman terhadap kondisi lahan kritis, kandungan logam-logam berat atau kekeringan. Upaya mengoptimalkan potensi, pengetahuan tentang mikoriza sangat relevan dengan semangat mengelola lahan pertanian yang ramah lingkungan teutama dibidang agribisnis. Gambut dapat menjadi sumber media (carier) yang murah dan efektif, gudang mikoriza indigenus di daerah tropis.

\section{DAFTAR PUSTAKA}

Brundrett, MN., B. Bougher, T.G. Dell, dan N. Malayczuk. 1996. Working with Microrhizas in Forestry and Agriculture. ACIAR Monograph 32. Australian Centre for International Agriculture Research Canberra.

Faiqoh. 2007. Metode Dasar bekerja dengan Mikoriza Arbuskula. Laboratorium Bioteknologi Hutan dan Lingkungan, Pusat Penelitian Sumber Daya Hayati dan Bioteknologi, Institut Pertanian Bogor, Bogor.

Johansson, JF., R.P. Leslie, dan D.F. Roger. 2004. Microbial Interactions in The
Mycorrhizosphere and Their Significance for Sustainable Agriculture. FEMS Microbiology Ecology 48 (2004) 1-13.

Kartika, E. 2000. Isolasi, Karakterisasi dan Pengujian Keefektivan Cendawan Mikoriza Arbuskular Terhadap Bibit Kelapa Sawit Pada Tanah Gambut Bekas Hutan. Jurnal Agronomi 10(2): 63-70.

Maftu'ah, E., M. Alwi, dan M. Willis. 2005. Potensi Makrofauna Tanah Sebagai Bioindikator Kualitas Tanah Gambut Bioscientiae Volume 2: 1. 2005, p. 114.

Puspitasari, D., K.I. Purwani, dan A. Muhibuddin. 2012. Eksplorasi Vesicular Arbuscular Mycorrhiza (VAM) Indigenous pada Lahan Jagung di Desa Torjun, Sampang Madura. Jurnal Sains Dan Seni ITS Surabaya 1 (2), September 2012.

Pacioni, G. 1992. Wet Sieving and Decanting Techniques for The Extraction of Spores of VA Mycorrhyzal Fungi. Methods in Microbiology. Academic Press Inc. San Diego 24: 317-322.

Sasli, I. dan A. Ruliansyah. 2012. Pemanfaatan Mikoriza Arbuskula Spesifik Lokasi untuk Efisiensi Pemupukan pada Tanaman Jagung di Lahan Gambut Tropis. Agrovigor 5 (2) September 2012.

Setiadi, Y. 2003. Arbuscular Mycorrhizal Inokulum Production. Program dan Abstrak Seminar dan Pameran: Teknologi Produksi dan Pemanfaatan Inokulan Endo-Ektomikoriza untuk Pertanian, Perkebunan, dan Kehutanan. 16 September 2003. Bandung. pp 10.

Simanungkalit, R. D. M. 2003. Teknologi Jamur Mikoriza Arbuskuler: Produksi 
Inokulan dan Pengawasan Mutunya. Program dan Abstrak Seminar dan Pameran: Teknologi Produksi dan Pemanfaatan Inokulan EndoEktomikoriza untuk Pertanian, Perkebunan, dan Kehutanan. 16 September 2003. pp 11.

Sundari, S., T. Nurhidayati, dan I. Trisnawati. 2012. Isolasi dan Identifikasi Mikoriza Indigenous dari Perakaran Tembakau Sawah (Nicotiana tabacum L.) di Area Persawahan Kabupaten Pamekasan Madura. Jurusan Biologi, Fakultas Matematika dan IImu Pengetahuan
Alam Institut Teknologi Sepuluh Nopember.

Twin, C. 2003. Pemanfaatan Mikoriza Dan Prospeknya. Program dan Abstrak Seminar dan Pameran: Teknologi Produksi dan Pemanfaatan Inokulan Endo-Ektomikoriza untuk Pertanian, Perkebunan, dan Kehutanan.16 September 2003. pp 15.

Yusnaini, S., A. Niswati, S. G. Nugroho, K. Muludi, dan A. Irawati. 1999. Pengaruh Inokulasi Mikoriza Vesikular Arbuskular terhadap Produksi Jagung yang Mengalami Kekeringan Sesaat pada Fase Vegetatif dan Generatif. Jurnal Tanah Tropika. No. 9:1-6. 